\title{
Demonstration of GAD-65 as the Main Immunogenic Isoform of Glutamate Decarboxylase in Type 1 Diabetes and Determination of Autoantibodies Using a Radioligand Produced by Eukaryotic Expression
}

Lício A. Velloso, Olle Kämpe, Anders Hallberg, Lars Christmanson, * Christer Betsholtz, “ and F. Anders Karlsson Departments of Internal Medicine and *Pathology, University Hospital, Uppsala, Sweden

\begin{abstract}
Plasmids containing cDNA for the rat 67- and 65-kD isoforms of glutamate decarboxylase (GAD-67 and GAD-65) were expressed in COS-cells, and lysates of $\left[{ }^{35} \mathrm{~S}\right]$ methionine-labeled cells were used for immunoprecipitations. Sera from $38 \mathrm{pa}-$ tients with type 1 (insulin-dependent) diabetes mellitus, which precipitated a 64-kD antigen from rat islets, reacted with recombinant GAD-65 in relation to their anti-64-kD titers. The eight strongest sera also precipitated recombinant GAD-67, suggesting that certain epitopes are common to both isoforms. Subsequently, $\left[{ }^{35} \mathrm{~S}\right]$ methionine-labeled GAD-65 was purified from COS cell lysates and employed in a binding assay with 50 sera of patients with recent onset of type 1 diabetes mellitus. 38 sera (76\%) precipitated labeled GAD-65 with titers that correlated with islet cell antibodies ( ICA), determined in a standard immunofluorescence assay. 2 sera were GAD positive but ICA negative, 4 were positive only for ICA, and 6 were negative for both GAD and ICA, as were the sera of 20 controls. The data illustrate that antibodies against GAD-65 are present in a majority of patients with type 1 diabetes mellitus and that autoantibodies against other islet cell antigens also exist. The radioligand-binding assay, which is convenient and sensitive for detecting GAD antibodies, will facilitate the screening of individuals with autoimmune islet cell disease. (J. Clin. Invest. 1993. 91:2084-2090.) Key words: autoantigen • autoimmunity • endocrine disease $\bullet$ islets of Langerhans - glutamic acid decarboxylase
\end{abstract}

\section{Introduction}

Type 1 (insulin-dependent) diabetes mellitus is an autoimmune disease, characterized by a progressive destruction of the insulin-producing $\beta$ cells and accompanied by the production of autoantibodies against different antigens in the islets of Langerhans (1-4). Antibodies against a $64-\mathrm{kD}$ protein have been reported to precede the clinical onset of insulin-dependent diabetes mellitus (4) and to be an useful predictor of the disease $(4,5)$. Baekkeskov and co-workers $(6)$ have recently recognized that the 64-kD antigen represents glutamic acid decarboxylase $(\mathrm{GAD})^{1}(6)$. This enzyme, which catalyzes the conver-

Address correspondence to Dr. Lício A. Velloso, Department of Internal Medicine, University Hospital, S-751 85 Uppsala, Sweden.

Received for publication 14 July 1992 and in revised form $30 \mathrm{No}$ vember 1992.

1. Abbreviations used in this paper: GAD, glutamic acid decarboxylase; ICA, islet cell antibodies; JDF, Juvenile Diabetes Foundation.

J. Clin. Invest.

(c) The American Society for Clinical Investigation, Inc.

0021-9738/93/05/2084/07 \$2.00

Volume 91, May 1993, 2084-2090 sion of glutamic acid into gamma-amino butyric acid, has been found in the brain, $\beta$ cells, kidneys, pituitary gland, thyroid, ovaries, testes, adrenals, and liver (7). Gamma-amino butyric acid is an inhibitory neurotransmitter in the central nervous system but its function in the $\beta$ cells is not known. A role in the paracrine signaling between $\beta$ cells and the neighboring $\alpha$ - and $\delta$ cells has been proposed (8), as well as a role in the energy metabolism of the $\beta$ cells (9).

To date two genetically distinct forms of GAD, GAD-67 and GAD-65, have been identified (10). The role of the two different isoforms as autoantigens in the immune response against islets in type 1 diabetes mellitus has not been established. Over the years, the precipitation of the $64-\mathrm{kD}$ antigen has been described in a number of studies using $\left[{ }^{35} \mathrm{~S}\right]-$ methionine-labeled lysates of rat or human islets and sera of patients with type 1 diabetes mellitus. Recently, the binding of antibodies to the 64-kD antigen was found to be blocked more efficiently by GAD-65 than by GAD-67 bacterial fusion proteins (11). The existence of antibodies against GAD-67 has been described in studies of GAD isoforms produced by recombinant DNA techniques $(11,12)$ and in recent experiments with immunoprecipitates of labeled islets $(12,13)$. However, in previous reports, antibodies recognizing the $64-\mathrm{kD}$ antigen or fragments thereof have been described repeatedly but not the presence of precipitating antibodies against proteins with molecular masses $>64 \mathrm{kD}$. Thus, the published data on the autoantibody response against the different forms of GAD are seemingly conflicting.

In this study, we used transient eukaryotic expression of GAD to examine the presence of autoantibodies against the isoforms in sera of patients with insulin-dependent diabetes mellitus. Since the results indicated GAD- 65 to be the primary antigenic isoform, we devised a rapid and convenient method for antibody quantitation.

\section{Methods}

Subjects. Sera from 88 individuals with type 1 diabetes mellitus and 20 healthy blood donors controls (between 22 and $65 \mathrm{yr}$ of age) were used. 38 sera, previously characterized and found to identify a 64-kD GAD protein from $\left[{ }^{35} \mathrm{~S}\right]$ methionine-labeled rat islet lysates, were employed in the first phase of the study. These sera differed in anti-64-kD titers from 1 to 3 on a three-point scale, as estimated from the fluorographic intensities of the precipitated $64-\mathrm{kD}$ protein bands. The patients were 25 females and 13 males between 6 and 71 yr and with a time course for the disease between $2 \mathrm{mo}$ and $2 \mathrm{yr}$. In the second phase, sera from 50 consecutive patients with newly diagnosed type 1 diabetes mellitus were examined for the presence of islet cell antibodies (ICA) in a standard immunofluorescence assay with frozen sections of human pancreas and for anti-GAD antibodies by the radioligand-binding assay. This group of patients consisted of 26 females and 24 males, between 5 and $44 \mathrm{yr}($ mean $=17.5 \mathrm{yr})$ and with a time course for the disease between 2 and $6 \mathrm{mo}$. 
Monoclonal antibody and antisera. The GAD-6 monoclonal antibody with GAD-65 specificity (14) and the GAD-6 hybridoma cell line were purchased from the Developmental Studies Hybridoma Bank, University of Iowa (Iowa City, IA). The hybridoma cells were kept in culture as recommended by the suppliers. The K-2 rabbit antiserum raised against feline GAD-67 produced by bacterial expression was a gift from Dr. Alan Tobin, University of California at Los Angeles. This antiserum is considered specific for GAD-67 (15). A sheep serum raised against purified rat brain GAD (NIMH 1440) (16), recognizing both GAD-67 and GAD-65, with a preference for the low molecular weight form, was a gift from Dr. I.J. Kopin and co-workers at the Laboratory of Clinical Sciences, NIMH National Institutes of Mental Health (Bethesda, MD).

Transient expression of GAD. Rat cDNA clones encoding for GAD-65 and GAD-67 (kindly provided by Dr. Alan Tobin) (10) were ligated into the HindIII and NotI sites of the pCDM8 vector (gift from Dr. Brian Seed, Massachusetts General Hospital, Boston, MA) (17). COS cells ( 18 ) that had grown to $80 \%$ confluence were harvested by a mild trypsin treatment and transfected by electroporation (19) with the GAD-65 or -67 plasmid. After $48 \mathrm{~h}$ of culture in DME (Nord Vacc, Skärholmen, Sweden) containing $10 \%$ FCS, the cells were first incubated for $1 \mathrm{~h}$ in methionine-free RPMI medium (Nord Vacc) and then for $12 \mathrm{~h}$ in medium supplemented with $\left[{ }^{35} \mathrm{~S}\right]$ methionine $(>1,100 \mathrm{Ci} /$ mmol; Amersham International, Amersham, UK). Cells were harvested with a rubber policeman and lysed for $1 \mathrm{~h}$ at $+4^{\circ} \mathrm{C}$ in a lysis buffer of $20 \mathrm{mM}$ Tris $/ \mathrm{Cl}, \mathrm{pH} 8.2$, containing $0.2 \%$ Triton X-100 (Eastman Kodak Co., Rochester, NY), 2 mM PMSF (Sigma Chemical Co., St. Louis, MO), $20 \mathrm{mM} \mathrm{NaCl}$, and $1 \%$ Trasylol $^{\circledR}$ (Bayer AG, Leverkusen, Germany). Insoluble membrane components were removed by centrifugation for $45 \mathrm{~min}$ at $100,000 \mathrm{~g}$ and the supernatants were used for the immunoprecipitation experiments and for the purification of the GAD-65 tracer.

Preparation of islet cell lysates. Islets of Langerhans from Wistar rats were isolated by hand after collagenase digestion following a previously described technique (20). The islets were maintained in culture for $72 \mathrm{~h}$ in RPMI medium containing $28 \mathrm{mM}$ glucose and $10 \% \mathrm{FCS}$. Internal labeling with $\left[{ }^{35} \mathrm{~S}\right]$ methionine and lysis were performed as described for the transfected COS cells. The lysates were stored at $-70^{\circ} \mathrm{C}$ for further immunoprecipitations.

Immunoprecipitation and electrophoresis. Gradient SDS-polyacrylamide gels $9-14 \%$ were assembled as previously published (21). Immunocomplexes were formed (22) with sera and lysates from transfected COS cells, rat islet lysates, or purified GAD tracer and were prepared for electrophoresis (22).

Determination of ICA. Titers were determined in an immunofluorescence assay using $6-\mu \mathrm{m}$ frozen sections of human pancreas. Serial dilution of sera were added to the sections, which were then incubated for $18 \mathrm{~h}$ in a moist chamber at $+4^{\circ} \mathrm{C}$. After washing with PBS, the slides were incubated with $50 \mu \mathrm{l}$ of FITC-conjugated rabbit anti-human IgG diluted 1:20 (Dakopatts, Glostrup, Denmark). The slides were mounted in Fluoromount (Southern Biotechnology Associates, Birmingham, $\mathrm{AL}$ ) and scored with regard to end point titers in a fluorescence microscope (Microphot FX; Nikon Inc., Garden City, NY). Titers are expressed in Juvenile Diabetes Foundation (JDF) units according to a linear regression between the end point dilutions of analyzed sera and a international reference serum (Fifth IDW ICA Proficiency Program). The cut-off in the ICA assay is 5 JDF units.

Purification of GAD. The supernatant of GAD-65 lysate $(1 \mathrm{ml})$ was applied on a DEAE-Sepharose (Pharmacia LKB Biotechnology Inc., Uppsala, Sweden $)$ column $(1.0 \times 0.5 \mathrm{~cm})$, preequilibrated with $10 \mathrm{vol}$ of $0.2 \mathrm{M}$ Tris/Cl, pH 8.2, followed by $10 \mathrm{vol}$ of lysis buffer. After sample application, the column was washed with $20 \mathrm{vol}$ of lysis buffer and then eluted with this to which $\mathrm{NaCl}$ had been added to a final concentration of $200 \mathrm{mM}$. Fractions of 0.2 column volumes were collected and the tubes containing the radioactive peak were pooled. Subsequently, the material was purified by affinity chromatography. CNBr-activated Sepharose (Pharmacia LKB Biotechnology Inc.) was coupled at a concentration of $5 \mathrm{mg}$ protein $/ \mathrm{ml}$ of gel with mouse antiGAD 65 monoclonal (GAD-6) purified by ammonium sulphate precipitation from supernatants of hybridoma cell cultures. The immunosorbent column was prepared according to recommendations from the manufacturer. The pool from the ion-exchange chromatography was loaded onto the GAD- 6 column at $+4^{\circ} \mathrm{C}$ and incubated for $2 \mathrm{~h}$. The column then was washed with $20 \mathrm{vol}$ of lysis buffer containing $500 \mathrm{mM}$ of $\mathrm{NaCl}$ and elution was performed with $0.2 \mathrm{M} \mathrm{Na}_{2} \mathrm{CO}_{3}, \mathrm{pH}$ 11.0. Fractions of 0.1 column volumes were collected in 0.01 column volumes of $1.0 \mathrm{M}$ Tris, $\mathrm{pH}$ 6.8. The eluted material was pooled and passed through a PD-10 column (Pharmacia LKB Biotechnology Inc.), equilibrated in $150 \mathrm{mM}$ Tris $/ \mathrm{Cl}$ buffer, $\mathrm{pH} 8.2$, containing $200 \mathrm{mM} \mathrm{NaCl}$, $0.02 \%$ Tween 20 (Sigma Chemical Co.), 2 mM PMSF, and $1 \%$ Trasylol®. Finally, the fractions eluted with the void volume were pooled and saved at $-70^{\circ} \mathrm{C}$ for further use as purified tracer.

Radioligand-binding assay for detection of reactivity against $G A D$. In the initial experiments, basal conditions for a radioligand assay were examined. Aliquots of $5 \mu \mathrm{l}$ of sera from patients and controls were incubated with $\sim 10.000 \mathrm{cpm}$ of the purified GAD tracer for $2 \mathrm{~h}$ at room temperature. Incubations overnight at $+4^{\circ} \mathrm{C}$ produced similar results (not shown). Subsequently, $25 \mu \mathrm{l}$ of a $20 \%$ suspension of Staphylococcus aureus (Cowan strain I) were added, and after 1-h of incubation at room temperature, immunocomplexes were collected by centrifugation. In separate experiments with $5-\mu \mathrm{l}$ aliquots of five different patient sera, between 10 and $15 \mu \mathrm{l}$ of $20 \%$ bacterial suspensions were found to achieve a complete precipitation of the GAD-65 tracer (not shown). The pellets were washed three times with a buffer containing $200 \mathrm{mM} \mathrm{NaCl}, 0.02 \%$ Tween 20, $2 \mathrm{mM}$ PMSF, and $1 \%$ Trasylol $\circledast$, and then were suspended in $4 \mathrm{ml}$ of scintillation liquid (Optiphase Hisafe II, LKB Scintillation Products, Uppsala, Sweden ) and total radioactivity was counted in an LKB $\beta$ counter. The washing of pellets with $0.1 \%$ Triton X-100 instead of $0.02 \%$ Tween 20 was tested and found to give higher background values (not shown). In each set of experiments, incubations with a positive patient serum (given the arbitrary titer of $100 \mathrm{U}$ ) as well as a negative control were included. The results of unknown serum samples were analyzed and given in GAD units (U) on the basis of the following method of calculation: unknown sample (cpm, mean of duplicate) - negative control (cpm, mean of duplicate) positive control (cpm, mean of duplicate) -negative control (cpm, mean of duplicate) $\times 100$. The interassay coefficient of variation determined from four separate assays was $6.7 \%$. The Spearman's rank correlation test was used for calculations of correlation.

\section{Results}

GAD-65 and GAD-67 as autoantigens in type 1 diabetes mellitus. To examine the relative importance of the two different isoforms of glutamate decarboxylase as autoantigens in type 1 insulin-dependent diabetes mellitus, lysates of $\left[{ }^{35} \mathrm{~S}\right]-$ methionine-labeled COS cells transfected with either the GAD67 or -65 plasmids were prepared and incubated with GAD antisera and patient sera. When examined by SDS-PAGE and fluorography, the specific GAD-67 rabbit antiserum (K2) immunoprecipitated a doublet of the 67 isoform and crossreacted weakly with the 65 isoform. The sheep GAD antiserum, known to react with both GAD-67 and -65, but predominantly with GAD-65, precipitated both the isoforms expressed in COS cells but primarily GAD-65 (Fig. 1). Subsequently, sera from 38 patients known to have antibodies that precipitate a $64-\mathrm{kD}$ protein from $\left[{ }^{35} \mathrm{~S}\right.$ ] methionine-labeled rat islet lysates were examined (Fig. 2, showing results of 7 out of 38 patients). 33 reacted against GAD- 65 and only 8 reacted against GAD67. None of the 38 sera had reactivity restricted to GAD-67 alone, but all 8 sera that reacted against GAD- 67 also reacted 


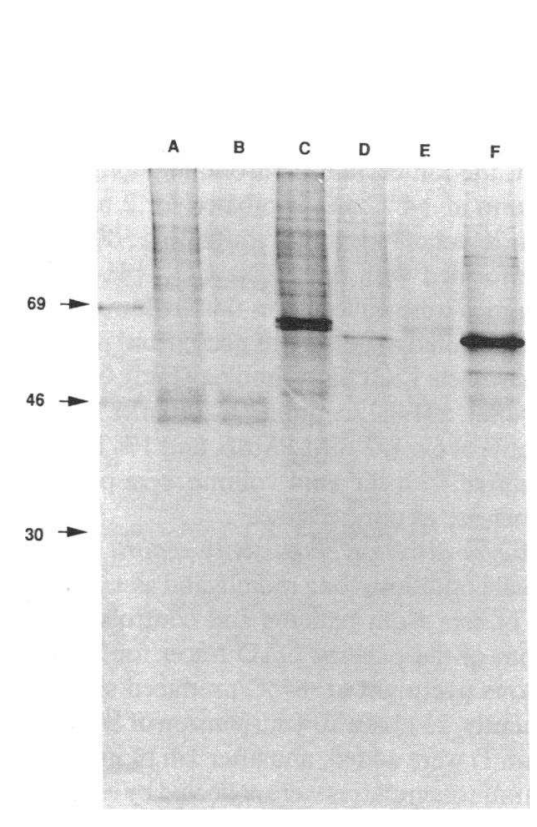

Figure 1. Lysates of $\left[{ }^{35} \mathrm{~S}\right]$ methioninelabeled COS cells transfected with plasmids containing rat GAD-67 (lanes $A, C$, and $E$ ) and GAD-65 (lanes $B, D$, and $F$ ) cDNAs, respectively, were immunoprecipitated with a rabbit anti-serum directed against human MHC class I antigens reacting with the simian MHC class I antigens in $\operatorname{COS}$ cells (lanes $A$ and $B$ ), with an anti-serum against GAD-67 (rabbit $\mathrm{K} 2$ serum; lanes $C$ and $D)$, and with an antiserum against GAD-67 (sheep NIMH 1440 serum; lanes $E$ and $F$ ).

strongly against GAD-65 (exemplified in Fig. 2 by sera IV and VII). These eight sera contained the highest anti-64-kD titers. In general, a relationship between the anti-64-kD titer and the precipitation of GAD-65 from cell lysates was apparent. When these 38 sera were examined by the radioligand-binding assay described below, all proved positive, including the 5 sera with the weakest anti-64-kD titer that did not precipitate recombinant GAD-65 from the COS cell lysate.

Purification of GAD-65 produced by eukaryotic expression. Lysates from COS cells that had been transfected with the GAD-65 plasmid and incubated with $\left[{ }^{35} \mathrm{~S}\right]$ methionine contained a large number of labeled proteins when examined by SDS-PAGE and fluorography (Fig. 3). The GAD-65 component was discernible as a single band accounting for $2-3 \%$ of the proteins. Purification of the lysate by DEAE ion-exchange chromatography resulted in an enrichment of the protein and, by using the anti-GAD-65 monoclonal (GAD-6) immunoaffinity column, a purity close to homogeneity in the SDS-PAGE analysis (Fig. 3, lane $C$ ) was obtained. When tested with an excess of the sheep anti-GAD serum (NIMH 1440), the frac- tion of labeled material precipitated in each purification step increased and a $>300$-fold purification of the tracer was achieved. Precipitates formed with patient sera and the tracer preparation contained only one major component corresponding to the $65-\mathrm{kD}$ protein, in marked contrast to precipitates from $\left[{ }^{35} \mathrm{~S}\right]$ methionine-labeled rat islet lysates, which typically included several nonspecific proteins in addition to the $64-\mathrm{kD}$ doublet (Fig. 4). This indicated that the tracer preparation would be useful for the detection of GAD antibodies in an assay superior to the standard technique based on labeled rat islet lysates.

Radioligand-binding assay. In initial experiments we determined the volume of patient sera required for the precipitation of the purified GAD-65 tracer. Fig. 5 shows results obtained with sera from six different patients and two controls. As can be seen, increasing amounts of serum increased the amount of radioactivity precipitated up to a maximum of $\sim 19 \%$. On the basis of this and two additional pilot experiments, a volume of $5 \mu \mathrm{l}$ of serum was considered optimal for allowing discrimination between high, moderate, and low titer for use in routine radioligand-binding assays. The maximum amount of radioactivity that could be precipitated with the sheep anti-GAD serum NIMH 1440 varied between 20 and $25 \%$ when tested with four different preparations of GAD-65 tracer. Precipitation of the tracer with trichloroacetic acid allowed full recovery of radioactivity, indicating that the preparation does not contain free or peptide-bound radioactivity. The most acceptable reason for the partial precipitation when using specific antiserum might be due to some degree of denaturation caused by the alkaline elution used. Likewise, a tracer eluted from the GAD-6 immunoaffinity column with $3 \mathrm{M}$ $\mathrm{KSCN}$ was only partially precipitable (between 18 and $22 \%$ ) with the GAD antiserum.

The 38 sera used in the initial experiments and known to precipitate a $64-\mathrm{kD}$ protein from $\left[{ }^{35} \mathrm{~S}\right]$ methionine-labeled rat islet lysates were examined in the radioligand-binding assay. All, including the five sera that showed no detectable precipitation of GAD-65 from the lysate of the COS cells transfected with the GAD-65 plasmid, were positive in the ligand-binding assay. 50 other sera from patients with type 1 diabetes mellitus were examined in the radioligand-binding assay and the results were compared with measurements of ICA in a standard immunofluorescence assay (Fig. 6). The majority $(38 / 50)$ of sera

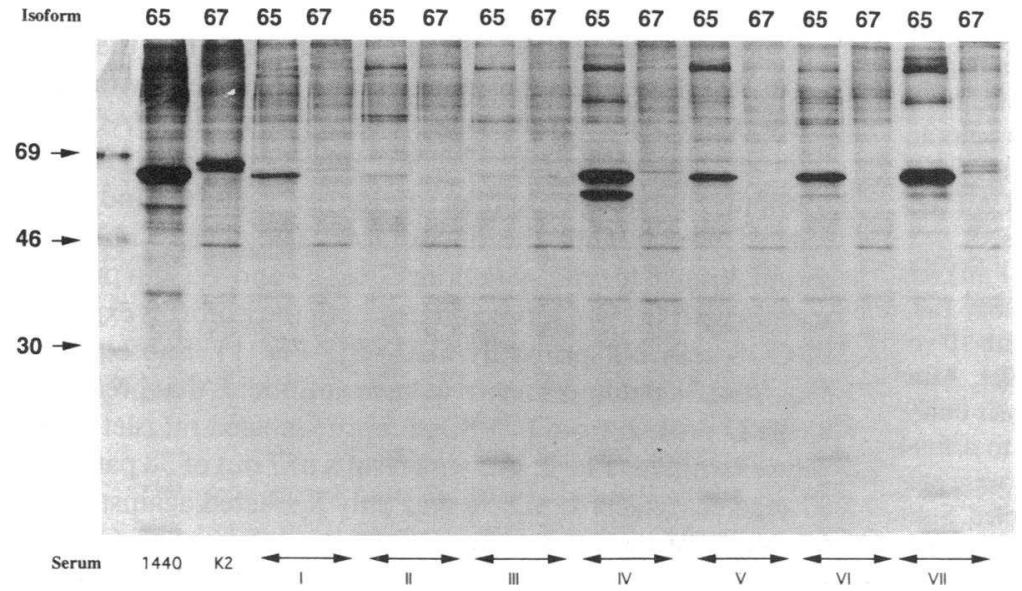

Figure 2. SDS-PAGE of immunoprecipitates collected from $\left[{ }^{35} \mathrm{~S}\right.$ ] methionine-labeled COS cells transfected with the cDNA encoding for GAD-65 and -67. In the upper margin the transfected isoform is indicated. In the lower margin is indicated the serum used in the immunoprecipitation, NIMH 1440 sheep anti GAD, K2 rabbit anti GAD-67, and sera from patients I to VII. Molecular mass markers are indicated in the left margin. 


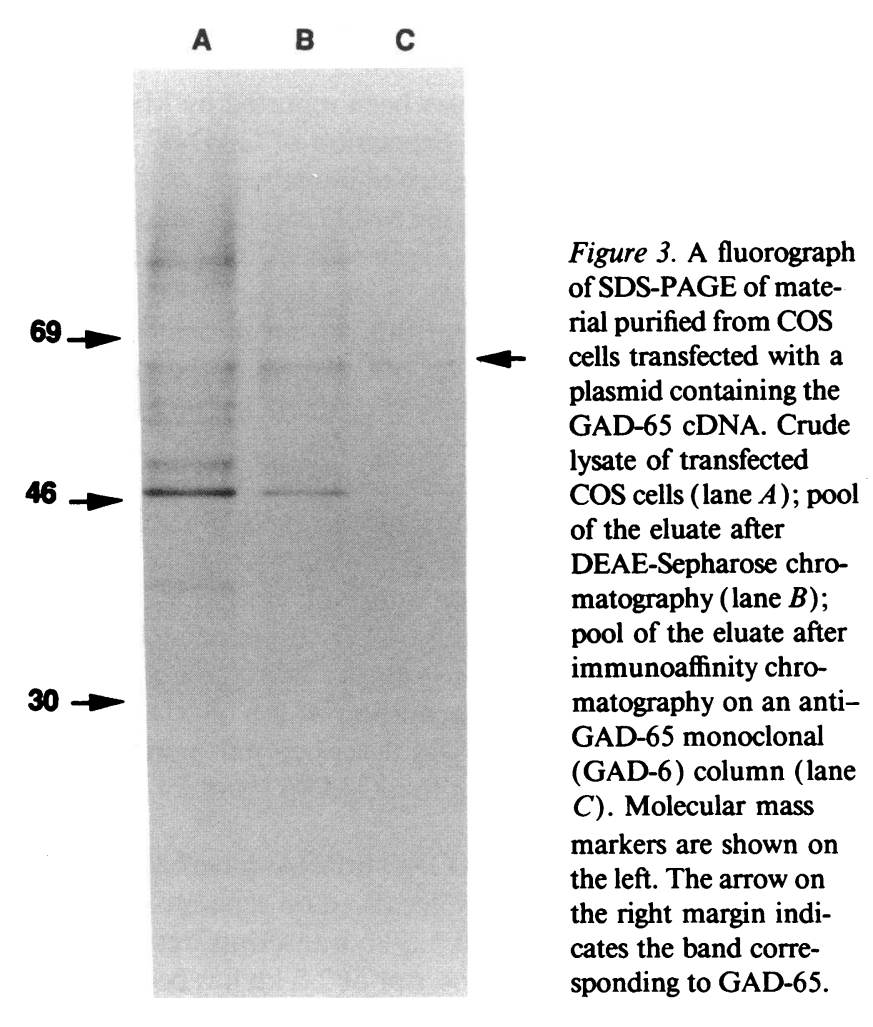

proved positive in both assays and a moderate but significant correlation was determined $\left(r_{\mathrm{s}}=0.45, P<0.001\right)$. Sera of 20 healthy blood donors did not contain any detectable ICA and all showed low background precipitation of the GAD- 65 tracer in the radioligand-binding assay. Two sera did bind GAD-65 in the ligand assay but were negative in the ICA test. Four sera were ICA positive but GAD-65 negative. These sera, when tested following a procedure described by Genovese and coworkers (23), stained the islets in a non- $\beta$ cell-restricted fashion, i.e., all islet cells did stain (examined in light microscopy of peroxidase-labeled rabbit anti-human IgG; not shown). The results with these two latter groups of sera were confirmed when repeated testings were carried out. Six patient sera did not have any autoantibodies detectable in the GAD-65 assay or the ICA assay.

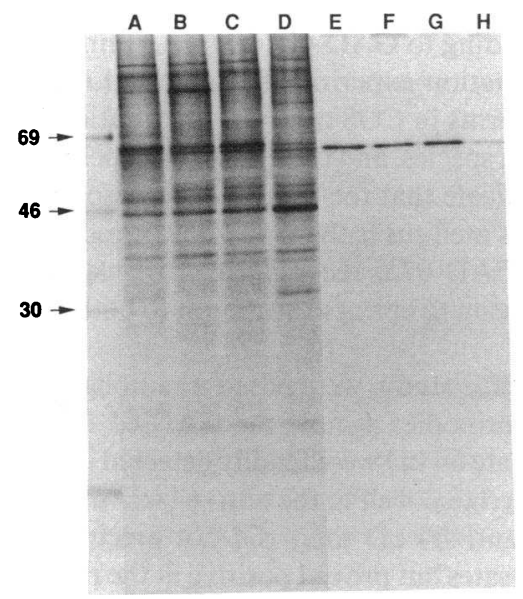
of SDS-PAGE of immunoprecipitates with four patient sera containing antibodies against the $64-\mathrm{kD}$ islet cell antigen, reacting with $\left[{ }^{35}\right.$ S $]$ methioninelabeled rat islet lysates (lanes $A-D$ ) and purified GAD-65 tracer (lanes $E-H$ ), respectively. The mobilities of molecular mass markers are indicated in the left margin.

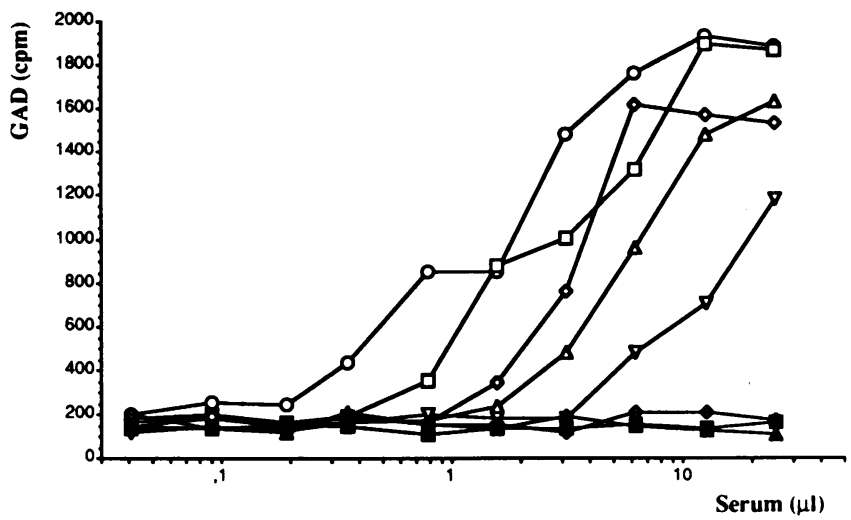

Figure 5. Effect of increasing amounts of serum on precipitation of GAD-65 tracer in a radioligand-binding assay. Six different sera of patients with type 1 diabetes mellitus, previously tested for their reactivity against the 64-kD autoantigen present in rat islets lysate, were used. The sera A-E had high to low ( 3 to 1 on a three-point scale) anti-64-kD protein reactivity, serum $F$ was anti-64-kD protein negative but stained all islet cells in a standard immunofluorescence assay (titer $1 / 64$ ), sera $G$ and $H$ were from healthy controls ( $\circ A, \square B, \triangle C$, $\diamond \mathrm{D}, \nabla \mathrm{E}, \diamond \mathrm{F}, \backsim \mathrm{G}, \triangle \mathrm{H})$.

\section{Discussion}

In the first part of this study, the different roles of the two isoforms of GAD as autoantigens in type 1 diabetes mellitus were examined. A set of patient sera known to contain GAD

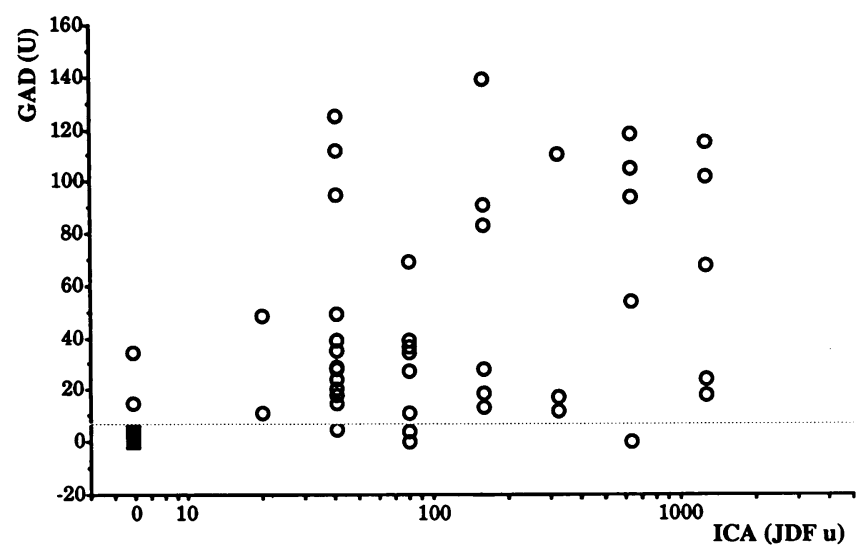

Figure 6. Comparison of autoantibody determinations in sera of patients with newly onset type 1 diabetes mellitus. Sera were examined in a radioligand GAD-65-binding assay (vertical) and a standard immunofluorescence islet cell antibody (ICA) assay using frozen sections of human pancreas (horizontal). Results for the radioligand GAD-65 assay are presented in GAD U according to the text, and results of the ICA detection assay are in Juvenile Diabetes Foundation (JDF) units. The dashed line indicates the upper normal limit in the GAD-65 assay (mean of controls $+2 \mathrm{SD}$ ). A correlation between ICA and GAD-65 titers is apparent. Note, however, that two sera scored positive in the GAD-65 assay but were ICA negative. Four sera scored positive in the ICA test but negative in the GAD-65 assay (these sera showed staining of all islet cells in the ICA test) ( $\mathrm{O}$ Patients; - Controls). 
antibodies as determined by their capacity to precipitate the 64-kD protein from rat islet lysates (3) was used, and their interaction with GAD-67 and -65 proteins produced separately by transient expression was studied. Rat cDNA coding for the two isoforms was inserted into eukaryotic expression vectors and the respective proteins were efficiently synthesised in a COS cell system. The amino acid sequences of the respective rat proteins display a homology $>95 \%$ when compared with that of the human counterparts (24) and the rat cDNA was therefore chosen for comparison with the reference method hitherto used, i.e., immunoprecipitation from rat islet lysates. In SDS-PAGE analysis, the GAD-65 protein migrated as a single component whereas the GAD-67 isoform, for reasons unknown, appeared as a doublet. Both isoforms were readily recognized by specific antisera. The K-2 rabbit antiserum, raised against bacterially produced feline GAD- 67 and considered specific for GAD-67, identified the GAD-67 protein doublet. This serum also reacted, though less avidly, with the GAD-65 protein. As expected, the rabbit serum raised against GAD purified from rat brain (NIMH 1440) reacted with both isoforms of GAD but displayed a clear preference for the GAD-65 protein.

Patient sera containing anti-GAD antibodies reacted primarily with GAD-65 and precipitated this protein from COS cell lysates to the same extent as they were able to precipitate a 64-kD protein from rat islets. None of the 38 sera examined contained antibodies against the GAD- 67 protein alone and all 8 sera with reactivity against GAD-67 displayed a much stronger reactivity against GAD-65. This suggests that the GAD-65 protein may act as the primary immunogen in type 1 diabetes mellitus. The GAD-65 and -67 proteins are homologous but display major amino acid differences in the first 100 amino acids at the $\mathrm{NH}_{2}$ terminal, where only 20 amino acids are identical (10). The ensuing almost 400 amino acids of the two proteins are very similar with only $22 \%$ amino acid exchanges, many of them conservative. The $\mathrm{COOH}$-terminal part of the proteins contains a common pyridoxal phosphatebinding site with the consensus sequence Asn-Pro-His-Lys also present in DOPA decarboxylase and probably contains the active site of the enzyme. The pronounced autoantibody discrimination between the GAD-65 and -67 gene products suggests that the dominant epitopes are present near the $\mathrm{NH}_{2}$ terminal of the GAD-65 protein.

The description of antibodies recognizing the GAD-67 isoform in sera of patients with type 1 diabetes mellitus has recently taken place. Kaufman et al. (11) reported that antibodies against both forms of GAD are found in patients at the onset of the disease and that the antibodies disappear with time, with the interesting exception of long-standing disease associated with neuropathy. Antibodies against both forms as well as individual sera reacting with only one of the two isoforms in an immunoblotting assay with bacterial fusion proteins were described. The fusion protein GAD-65 was found to block all reactivity against the $64-\mathrm{kD}$ protein precipitating from $\left[{ }^{35} \mathrm{~S}\right]$ methionine-labeled rat islet lysates whereas a 10 times greater amount of bacterial fusion protein GAD-67 only produced a partial inhibition. Their data are compatible with the suggestion that autoantibodies are primarily formed against GAD-65 in type 1 diabetes mellitus and that anti-GAD-67 antibodies merely reflect cross-reactivity with common epitopes. Certain sera that recognize only the GAD-67 have been reported, however, and it is difficult to reconcile this finding with the former suggestion. This phenomenon requires further elucidation.

GAD-67 antibodies have also been reported by Michelsen et al. (12) who used transient expression of GAD-67 in COS cells as well as lysates of $\left[{ }^{35} \mathrm{~S}\right]$ methionine-labeled rat islets. All 10 sera selected for recognizing the $64-\mathrm{kD}$ islet cell antigen were found to bind to the transiently expressed GAD-67 protein and to identify a $67-\mathrm{kD}$ component in the islets. However, it is difficult to assess to what extent this system measured crossreactivity with GAD-67 since no comparison of the autoantibody reactivity against transiently expressed GAD-65 was performed. Christgau et al. (13) have described GAD-67 antibodies in a study of $\left[{ }^{35} \mathrm{~S}\right]$ methionine-labeled rat islet lysates, incubated with patient sera, and analyzed by SDS-PAGE. The system used had been used in several previous reports without any mention being made of an antigenic component with a mobility slower than that of the $64-\mathrm{kD}$ component. Furthermore, in a previous paper describing the 2-D resolution of rat and human islet antigens, a separation of the $64-\mathrm{kD}$ component into an $\alpha$ and a $\beta$ form was described, but no evidence of a component corresponding to a GAD-67 protein was presented (25).

Interesting observations on GAD mRNAs have been made. The GAD-67 and - 65 genes are localized on separate chromosomes and give rise to $3.7-$ and $5.6-\mathrm{kb}$ transcripts, respectively (10). In addition, a major transcript of $2.5 \mathrm{~kb}$ has been found in mRNA from testis (26). The expression of the mRNAs differ among tissues and also species differences seem to exist. Both the GAD-67 3.7-kb and the GAD-65 5.6-kb transcripts have been found in the brain tissue of different species. In human islets only the GAD-65 5.6-kb transcript has been found (27). In contrast, both forms of GAD seems to be expressed in rat islets, since the GAD-65 mRNA is present (26) and also a GAD-67 cDNA has been isolated from a rat islet library (12).

In rat islets, both the GAD-67 and -65 proteins are expressed with the GAD- 65 form as the predominant one. Thus, the GAD-6 monoclonal antibody against the 65-kD form stains human $\beta$ cells and brain sections to an equal extent, whereas the rabbit antisera K-2, considered specific for GAD67 , stains islets less than brain tissue. The K-2 serum also stain human islets (11). The stain is however markedly different from the strong stain obtained with brain sections (28). The weak human islet cell stain may be due to anti-GAD-67 antibodies cross-reacting with GAD-65 in human islets. Furthermore, we have found that sera of patients precipitate a single band from labeled human islet lysates corresponding to GAD65 but no band corresponding to GAD-67 (29). In summary, the data from the precipitation experiments in labeled islets, transiently expressed isoforms in COS cells, the distribution of mRNA in islets in different species, and the immunohistochemical stainings strongly indicate that the immunogenic isoform of GAD in type 1 diabetes mellitus is the GAD-65 component and that, in cases where GAD-67 is recognized, cross-reactive GAD-65 autoantibodies react to epitopes common to both isoforms.

In the second part of this study, we devised a radioligandbinding assay to detect antibodies against the GAD-65 form. All sera known to precipitate $64 \mathrm{kD}$ were readily detected in the radioligand assay and correlated well to the anti-64-kD titer. 5 of the 38 sera with low anti-64-kD titers did not precipitate GAD- 65 from COS cell lysates but proved positive in the radio- 
ligand-binding assay. In the sera of 50 patients with newly onset type 1 diabetes mellitus, we noted that 2 of 50 sera proved positive in the ligand assay but were ICA negative when examined on sections of human pancreas. In this context, it could be mentioned that Christie et al. (30) have reported that when a 64-kD antigen preparation was modified by trypsin treatment, previously negative sera became antibody positive, presumably by recognizing epitopes hidden in the native antigen. In all, the present data suggest that the ligand-binding assay is not only more convenient but also more sensitive than using analysis by SDS-PAGE and fluorography of immunoprecipitates from $\left[{ }^{35} \mathrm{~S}\right]$ methionine-labeled islet lysates.

Two sera were ICA negative and GAD-65 positive as mentioned above and four sera were strongly ICA positive but still GAD-65 negative. The ICA-positive/GAD-65-negative sera stained all islet cells, i.e., the stain was not confined exclusively to the insulin-producing $\beta$ cells, which is often found with sera having high titers of GAD antibodies in patients with type 1 diabetes mellitus and typically in stiff-man syndrome (6). The sera did not precipitate any specific component from $\left[{ }^{35} \mathrm{~S}\right]-$ methionine-labeled rat islet lysates, suggesting that the antibodies are directed against a nonprotein component present in all islet cells. The nature of this antigen remains obscure.

As shown by many investigators $(4,5)$, autoantibodies against $64 \mathrm{kD} / \mathrm{GAD}$ have a high predictive value when assessing the risk of developing diabetes. Initial observations on the presence of long-standing GAD autoantibodies in cases with severe neuropathy have also been made (12). Thus, a simple assay for GAD antibodies would be of great value not only for predicting the risk of developing diabetes in relatives but also for estimating the risk in patients of developing complications. It may also be useful in monitoring future immunotherapy in newly diagnosed patients or individuals at high risk of developing the disease. Recently, an assay for the determination of GAD antibodies based on the iodination of a GAD preparation from pig brain (31) and an assay based on enzyme trapping have been published (32). The iodination of a semipure antigen can result in a heterogeneous tracer and reduce sensitivity. A method based on enzyme trapping will produce falsely low values if antibodies reactive with the active sites are present. This is not unlikely, since autoantibodies inhibiting the function of enzymes have been described $(33,34)$. The radioligand assay of the present study based on a recombinantly produced internally labeled radioligand permits an easily repeated test, correlates well with previously used ICA determinations, and is extremely sensitive. The test will facilitate screening for individuals with an ongoing destruction of islet cells and help in monitoring the course of the autoimmune response in type 1 diabetes mellitus.

\section{Acknowledgments}

We thank M. Ericsson and A.-C. Sundell for excellent technical assistance, Dr. A. J. Tobin for the gift of K-2 antiserum, Dr. I. J. Kopin for the gift of NIHM 1440 serum, Dr. B. Seed for the gift of the CDM8 vector, and Dr. L. Rask for the gift of a rabbit anti-human MHC class I antiserum and the $S$. aureus (Cowan strain I).

This study was supported by Swedish Medical Research Council Grant 4996, Torsten and Ragnar Söderbergs Foundation, Swedish Diabetes Association, Nordic Insulin Foundation, and Novo Nordisk.

\section{References}

1. Bottazzo, G. F., A. Florin-Christiansen, and D. Doniach. 1974. Islet cell antibodies in diabetes mellitus with autoimmune polyendocrine deficiencies. Lancet. ii:1279-1282.

2. Lendrum, R., G. Walker, A. G. Cudworth, C. Theophanides, D. A. Pyke, A. Bloom, and D. R. Gamble. 1976. Islet cell antibodies in diabetes mellitus. Lancet. ii:1273-1276.

3. Baekkeskov, S., J. H. Nielsen, B. Marner, T. Bilde, J. Ludvigsson, and Å. Lernmark. 1982. Autoantibodies in newly diagnosed diabetic children immunoprecipitate human pancreatic islet cell proteins. Nature (Lond.). 298:167-169.

4. Baekkeskov, S., M. Landin, J. K. Kristensen, S. Srikanta, G. J. Bruining, T. Mandrup-Poulsen, C. de Beaufort, J. S. Soeldner, G. Eisenbarth, F. Lindgren, et al. 1987. Antibodies to a $64,000 \mathrm{Mr}$ human islet cell antigen precede the clinical onset of insulin-dependent diabetes. J. Clin. Invest. 79:926-934.

5. Atkinson, M. A., N. K. Maclaren, D. W. Sharp, P. E. Lacy, and W. J. Riley. 1990. $64000 \mathrm{Mr}$ autoantibodies as predictors of insulin-dependent diabetes. Lancet. 335:1357-1360.

6. Baekkeskov, S., H.-J. Aanstoot, S. Christgau, A. Reetz, M. Solimena, M. Cascalho, F. Folli, H. Richter-Olesen, and P. De Camilli. 1990. Identification of the $64 \mathrm{~K}$ autoantigen in insulin-dependent diabetes as the GABA-synthesizing enzyme glutamic acid decarboxylase. Nature (Lond.). 374:151-156.

7. Christie, M. R., T. J. Brown, and D. Cassidy. 1992. Binding of antibodies in sera from type 1 (insulin-dependent) diabetic patients to glutamate decarboxylase from rat tissues. Evidence for antigenic and non-antigenic forms of the enzyme. Diabetologia. 35:380-384.

8. Rorsman, P., P.-O. Berggren, K. Bokvist, H. Ericsson, H. Möhler, C.-G. Östensson, and P. A. Smith. 1989. Glucose inhibition of glucagon secretion in volves activation of GABA-A receptor chloride channels. Nature (Lond.). 341:233-236.

9. Sorenson, R. L., D. G. Garry, and T. C. Brelje. 1991. Structural and functional considerations of GABA in islets of Langerhans. Diabetes. 40:1365-1374.

10. Erlander, M. G., N. J. K. Tillakaratne, S. Feldblum, N. Patel, and A. J. Tobin. 1991. Two genes encode distinct glutamate decarboxylases. Neuron. 7:91100.

11. Kaufman, D. L., M. G. Erlander, M. Claire-Salzler, M. A. Atkinson, N. K. Maclaren, and A. J. Tobin. 1992. Autoimmunity to two forms of glutamate decarboxylase in insulin dependent diabetes mellitus. J. Clin. Invest. 89:283-292.

12. Michelsen, B. K., J. S. Petersen, E. Boel, A. Moldrup, T. Dyrberg, and O. D. Madsen. 1991. Cloning, characterization, and autoimmune recognition of rat islet glutamic acid decarboxylase in insulin-dependent diabetes mellitus. Proc Natl. Acad. Sci. USA. 88:8754-8758.

13. Christgau, S., H. Schierbeck, H.-J. Aanstoot, L. Aagaard, K. Begley, H. Kofod, K. Hejnaes, and S. Baekkeskov. 1991. Pancreatic $\beta$-cells express two autoantigenic forms of glutamic acid decarboxylase, a $65-\mathrm{kDa}$ hydrophilic form and a 64-kDa amphiphilic form which can be both membrane-bond and soluble. J. Biol. Chem. 266:21257-21264.

14. Chang, Y.-C., and D. I. Gottlieb. 1988. Characterization of the proteins purified with monoclonal antibodies to glutamic acid decarboxylase. $J$. Neurosci. 8:2123-2130.

15. Kaufman, D. L., C. R. Houser, and A. J. Tobin. 1991. Two forms of $\gamma$-aminobutyric acid synthetic enzime glutamate decarboxylase have distinct intraneuronal distributions ant cofactor interactions. J. Neurochem. 56:720-723.

16. Oertel, W. H., D. E. Schmechel, M. L. Tappaz, and I. J. Kopin. 1981. Production of a specific antiserum to rat brain glutamic acid decarboxylase by injection of an antigen-antibody complex. Neuroscience. 6:2689-2700.

17. Seed, B. 1987. An LFA-3 cDNA encodes a phospholipid linked membrane protein homologous to its receptor CD2. Nature (Lond.). 329:840-844.

18. Gluzman, Y. 1982. SV40-transformed simian cells support the replication of early SV40 mutants. Cell. 23:175-182.

19. Chu, G., H. Hayakawa, and P. Berg. 1987. Electroporation for efficient transformation of mammalian cells with DNA. Nucleic Acids Res. 15:13111326.

20. Andersson, A. 1978. Isolated mouse pancreatic islets in culture: effects of serum and different culture media on the insulin production of the islets. Diabetologia. 14:397-404

21. Blobel, G., and B. Dobberstein. 1975. Transfer of proteins across membranes I. J. Cell Biol. 67:835-851.

22. Kämpe, O., A. Andersson, E. Björk, A. Hallberg, and F. A. Karlsson. 1989. High-glucose stimulation of $64,000 \mathrm{Mr}$ islet antigen. Diabetes. 38:13261328.

23. Genovese, S. B. E., J. M. McNally, B. M. Dean, R. Wagner, E. Bosi, E. A. M. Gale, and G. F. Bottazzo. 1992. Distinct cytoplasmic islet cell antibodies with different risks for type 1 (insulin dependent) diabetes mellitus. Diabetologia. 35:385-388.

24. Bu, D.-F., M. G. Erlander, B. C. Hitz, N. J. K. Tillakaratne, D. L. Kaufman, C. B. Wagner-McPherson, G. A. Evans, and A. J. Tobin. 1992. Two human 
glutamate decarboxylases, 65-kDa GAD and 67-kDa GAD, are each encoded by a single gene. Proc. Natl. Acad. Sci. USA. 89:2115-2119.

25. Baekkeskov, S., G. Warnock, M. Christie, R. V. Rajotte, P. M. Larsen, and S. Fey. 1989. Revelation of specificity of 64K autoantibodies in IDDM serums by high-resolution 2-D gel electrophoresis. Diabetes. 38:1133-1141.

26. Persson, H., M. Pelto-Huikko, M. Metsis, O. Söder, S. Brené, S. Skog, T. Hökfelt, and E. M. Ritzén. 1990. Expression of the neurotransmitter-synthesizing enzyme glutamic acid decarboxylase in male germ cells. Mol. Cell. Biol. 10:47014711 .

27. Karlsen, A. E., W. A. Hagopian, C. E. Grubin, S. Dube, C. M. Disteche, D. A. Adler, H. Bärmeier, S. Mathewes, F. J. Grant, D. Foster, et al. 1991. Cloning and primary structure of a human islet isoform of glutamic acid decarboxylase from chromosome 10. Proc. Natl. Acad. Sci. USA. 88:8337-8341.

28. Velloso, L. A., O. Kämpe, D. L. Eizirik, A. Hallberg, A. Andersson, and F. A. Karlsson. 1993. Human autoantibodies react with GAD-antigen in human and rat but not in mouse pancreatic islets. Diabetologia. 36:39-46.

29. Björk, E., O. Kämpe, F. A. Karlsson, D. G. Pipeleers, A. Andersson, C. Helleström, and D. L. Eizirik. 1992. Glucose regulation of the autoantigen GAD65 in human pancreatic islets. J. Clin. Endocrin. Metabol. 75:1574-1576.
30. Christie, M. R., G. Vohra, P. Champagne, D. Daneman, and T. L. Delovitch. 1990. Distinct antibody specificities to a $64-\mathrm{kD}$ islet cell antigen in type 1 diabetes is revealed by trypsin treatment. J. Exp. Med. 172:789-794.

31. Rowley, M. J., I. R. MacKay, Q. Y. Chen, W. J. Knowles, and P. Z. Zimmet. 1992. Antibodies to glutamic acid decarboxylase discriminate major types of diabetes mellitus. Diabetes. 41:548-551.

32. Thiovolet, C. H., M. Tappaz, A. Durand, J. Petersen, A. Stenutti, P. Chatelain, B. Vialettes, W. Scherbaum, and J. Orgiazzi. 1992. Glutamic acid decarboxylase (GAD) autoantibodies are additional predictive markers of type 1 (insulin-dependent) diabetes mellitus in high risk individuals. Diabetologia. 35:570-576.

33. Uibo, R., I. R. Mackay, M. Rowley, P. Humphries, J. Armstrong, and J. McNeilagse. 1989. Inhibition of enzyme function by human autoantibodies to an autoantigen pyruvate dehydrogenase E2: different epitope for spontaneous human and induced rabbit autoantibodies. Clin. Exp. Immunol. 80:19-24.

34. Burman, P., S. Mårdh, L. Norberg, and F. A. Karlsson. 1989. Parietal cell antibodies in pernicious anemia inhibit $\mathrm{H}^{+}, \mathrm{K}^{+}$-adenosine triphosphatase, the proton pump of the stomach. Gastroenterology. 96:1434-1438. 